\title{
鉛直ジョイント部の剥離・滑動を考慮した アーチダム堤体の振動特性および常時挙動評価
}

\author{
松田 泰治 1 - 大熊 信之 ${ }^{2} \cdot$ 遠藤 $\quad$ 洋平 $3 \cdot$ Elif Cargda KANDEMIR $^{4}$ \\ 1正会員 熊本大学大学院 自然科学研究科 環境共生工学専攻教授 \\ ( ( 860-8555 熊本県熊本市黒髪2丁目39番地1号) \\ E-mail:mazda@kumamoto-u.ac.jp \\ 2正会員 九州電力株式会社 総合研究所 土木グループ研究員 \\ ( (815-8520 福岡県福岡市南区塩原2丁目1番地47号) \\ E-mail:Nobuyuki_Ookuma@kyuden.co.jp \\ 3 学生会員 熊本大学大学院 自然科学研究科 社会環境工学専攻 \\ ( ( 860-8555 熊本県熊本市黒髪2丁目39番地1号) \\ E-mail:104d8805@st.kumamoto-u.ac.jp \\ 4学生会員 熊本大学大学院 自然科学研究科 環境共生工学専攻 \\ ( ( 860-8555 熊本県熊本市黒髪2丁目39番地1号) \\ E-mail:091d9411@st.kumamoto-u.ac.jp
}

\begin{abstract}
アーチダムは薄肉な三次元構造物であり，耐荷機構および振動特性は基礎岩盤および貯水との相互作用 に大きく影響される ${ }^{1)}$. 施工時に設けられる鉛直ジョイント部は, 剥離・滑動挙動が確認されており, 解析 モデルにおける鉛直ジョイント部を適切に評価する必要がある. また, アーチダムの堤体形状はダムサイ 卜毎に多種多様であるにもかかわらず，堤体形状が応力状態に及ぼす影響については十分に検討されてい ない. そこで本研究では, 鉛直ジョイント部の非線形特性を考慮できる解析モデルを構築し, 堤体形状と して左右対称性および非対称性に着目した。実在するアーチダムから作成したダム一岩盤連成系の三次元 モデルを非対称モデルと位置づけ，非対称モデルをもとに左右対称的な堤体を有するモデルを 2 ケス構築 した. さらにそれぞれの解析モデルを対象として固有值解析, 常時挙動解析を実施し, アーチダムの基本 的な振動特性および而荷機構について示し, 鉛直ジョイント部の非線形特性および堤体形状がこれらに及 ぼす影響について検討した。
\end{abstract}

Key Words : arch dam, transverse joints, mode shape, static behavior

\section{1. はじめに}

我が国のコンクリートダムは現行の耐震設計法である 震度法により設計されている2). 震度法で設計されたダム は, 1995年の兵庫県南部地震やそれ以降に発生した大規模 地震に対しても大きな被害を受けた事例はないことから, 十分な而震性を有していることが確認されている.しかし ながら,震度法による設計は必ずしも堤体挙動の実態に即 したものではなく, 種々の不確実性を高い安全率でカバー してきたのが実情であり, 想定以上の大規模地震動に対す るダムの健全性については適切に評価できていないこと が指摘されている゙).

アーチダムの堤体コンクリートを打設する際, 冷却収縮 に伴うひび割れを防止するため, ダム軸方向に $15 〜 20 \mathrm{~m}$ 間 隔て鈆直ジョイントが設けられる.鋁直ジョイント部は堤 体全体の剛性から考えれば弱部であり,最も変形が生じや
すい箇所と考えられる.鉛直ジョイント部の変位計測デー タや地震時挙動シミュレーション解析結果から, 温度変化, 貯水位変動, 地震動により鉛直ジョイント部は剥離・滑動 挙動を示すことが報告されている゙ 。さらにアーチダムは, 貯水の水圧等の荷重を基礎岩盤に伝達させる構造物であ り,コンクリートの持つ圧縮強度を最大限に利用できる薄 さまで堤体断面を小さくすることができる. そのため, ダ ムサイトの地形・地質を踏まえた上で安全性・経済性とい った二律背反する要求を確保するための堤体設計は設計 者に委ねられ,その結果として堤体形状はダム毎に多様と なる. しかしながら, 堤体形状がダムの耐荷機構に及ぼす 影響は十分に解明されていない.

本研究の目的は, 鉛直ジョイント部の非線形特性および 堤体形状として左右対称性・非刘称性に着目し, これらが 振動モードに対して及ぼす影響や大規模地震に対する応 答および堤体内部の応力状態に与える影響を把握するこ 
とである.

本論文では, 鉛直ジョイント部の非線形特性を考慮した 解析モデルを構築した. また, 実在するアーチダムをもと に精緻に作成された解析モデルを左右非対称モデルと位 置づけ，非対称モデルをもとに2ケースの左右対称モデル を構築した.これらの解析モデルに対して固有值解析を実 施し，それぞれの振動特性を把握した. また，アーチダム の地震時応答には常時における応力状態の与える影響が 大きいことから, 地震応答解析の事前検討として, 常時挙 動解析を実施することにより, 常時の応力状態に対して堤 体の対称性・非刘称性が及ぼす影響について検討した. な お, 本研究には, 汎用構造解析プログラムTDAPIII ${ }^{5}$ を使 用した.

\section{2. 解析モデル}

\section{(1) 非対称モデル}

本解析では, 実在する一基のアーチダムをもとに, 精緻 に再現した解析モデルを作成した.この解析モデルを非対 称モデルと定義する. 図-1 に示寸ように, ダム-岩盤連成 系の三次元モデルであり, 堤高・堤頂長はそれぞれ $110 \mathrm{~m}$,

$341 \mathrm{~m}$, 岩般幅は $45 \mathrm{~m}$ 等厚としている. 特徽として, 左 岸側にダム堤体に発生するアーチ推力を基礎岩盤に伝達 させる役割を持つスラストブロックを有する. 堤体並びに 岩盤部は等方弾性体として8節点6面体要素を用い, 堤体は 鉛直ジョイント (図-1の赤線部) 間を均等2分割，厚さ方 向に均等5分割している. 貯水は流体要素とはせず，地震 時に堤体上流面に作用する動水圧の影響は付加質量によ り与えた. 表-1に固有值解析および常時挙動解析に用いた 物性值をそれぞれ示す.これらの物性值は実ダム設計值を 参考にして設定した.

\section{(2) 鉛直ジョイント}

鋁直ジョイント部は, 節点ばね要素で構成し, 非線形解 析においては既往の研究) で提案された力学モデルを用 いた. 図-2に本モデルの概要を示す. 滑動・剥離の判定基

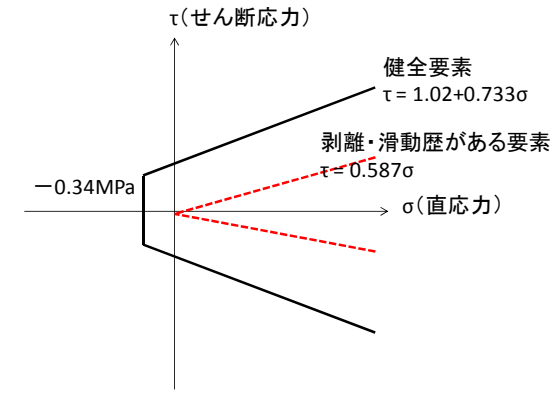

(a) 剥離と滑動特性の判定基準

(a) 剥離と滑動特性の半定基涪
準をCoulomb則で定義し, 判定基準を超えた鉛直ジョイン 卜部は剥離方向および滑動方向の応力を開放した. また再 接触した場合は圧縮応力の夕を完全に伝達させ,引張抵抗 をゼロとした。

\section{(3) 対称モデルの構築}

非刘称モデルの左右岸中央断面を対称面として折り返 すことで，2ケースの対称モデルを構築した. 図-3に対称 モデル構築の概略図を示寸.非対称モデルの右岸側を折り 返したものを右刘称モデル, 左岸側を折り返したものを左 対称モデルと定義した. 図-4に各モデルの正面図, 上面図 を示す。

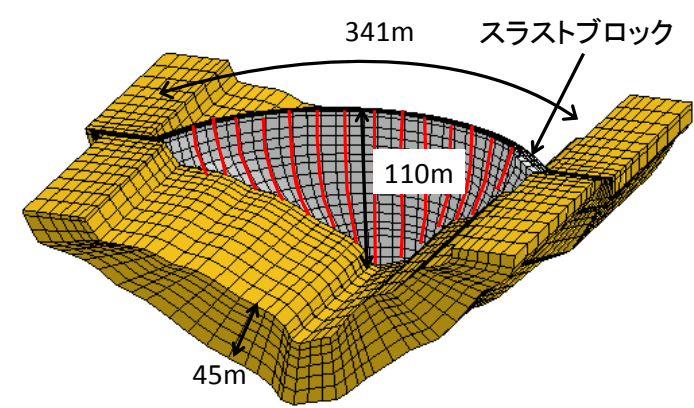

図-1＼cjkstart非対称モデルの鳥㒈図

表-1 解析モデルの物性值

(a) 固有值解析で用いた物性值

\begin{tabular}{|c|c|c|c|}
\hline & $\begin{array}{c}\text { 単位体積重量 } \\
\left(\mathrm{kN} / \mathrm{m}^{3}\right)\end{array}$ & $\begin{array}{c}\text { ヤング係数 } \\
\left(\mathrm{kN} / \mathrm{mm}^{2}\right)\end{array}$ & ポアソン比 \\
\hline 堤体コンクリート & 23.95 & 44.1 & 0.167 \\
\hline 鉛直ジョイント & 23.95 & 8.83 & 0.167 \\
\hline 岩盤 & 25.50 & 19.6 & 0.200 \\
\hline ゲート & 1.71 & 0.44 & 0.167 \\
\hline
\end{tabular}

(b) 常時挙動解析で用いた物性值

\begin{tabular}{|c|c|c|c|}
\hline & $\begin{array}{c}\text { 単位体積重量 } \\
\left(\mathrm{kN} / \mathrm{m}^{3}\right)\end{array}$ & $\begin{array}{c}\text { ヤング係数 } \\
\left(\mathrm{kN} / \mathrm{mm}^{2}\right)\end{array}$ & ポアソン比 \\
\hline 堤体コンクリート & 23.95 & 36.0 & 0.167 \\
\hline 鋁直ジョイント & 23.95 & 8.83 & 0.167 \\
\hline 岩盤 & 25.50 & 4.00 & 0.167 \\
\hline ゲート & 2.40 & 0.30 & 0.167 \\
\hline
\end{tabular}
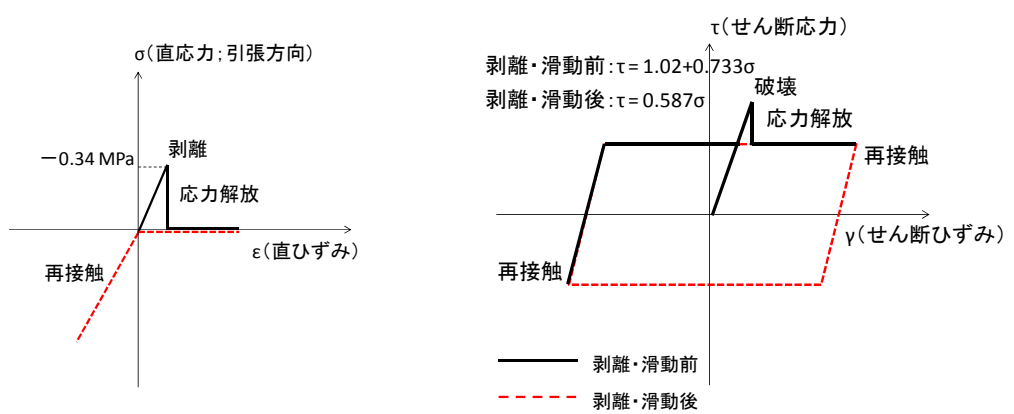

(b) 応力ーひず夕の履歴特性

図-2＼cjkstart鉛直ジョイント部のモデル化 


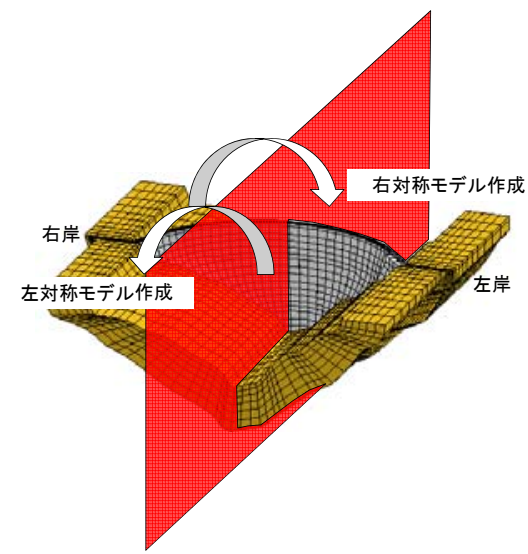

図-3＼cjkstart対称モデル構築の概略図
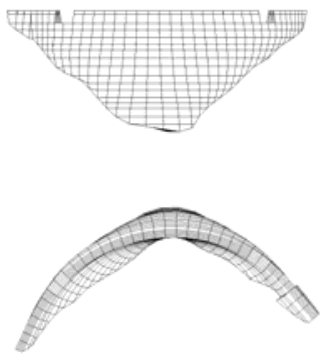

(a) 非対称モデル
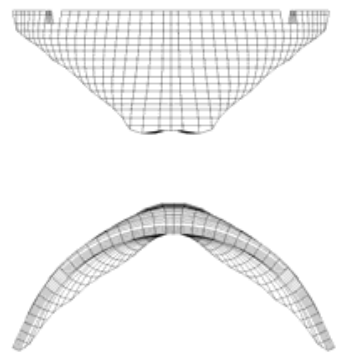

(b) 右対称モデル
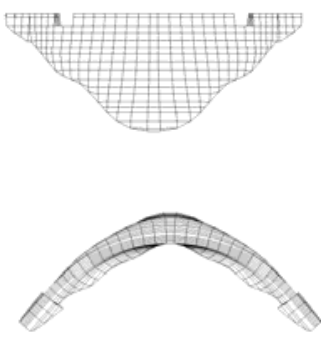

(c) 左対称モデル

図-4 解析モデル（堤体のみ）の正面図と上面図

\section{（4）付加質量法による動水圧の考慮}

地震時には, ダム堤体に常時作用している静水圧に加え て動水圧が作用する. 堤体上流側表面に質量を付加し，質 量の慣性力をもって近似的に動水圧を考慮した. 付加質量 の算定式には，「建設省河川砂防技術基淮（案）解説」6) に従い，堤体上流面勾配の影響を考慮できるZangarの式 (式(1),(2),(3)）を採用し, 付加質量は上下流方向にのみ与 えた. 図-5にZangarの式の堤体勾配 $\theta$ と補正係数 $C_{m}$ の関係 を示す.

$$
\begin{gathered}
M=C \cdot W_{0} \cdot H \\
C=\frac{C_{m}}{2}\left[\frac{h}{H}\left(2-\frac{h}{H}\right)+\sqrt{\frac{h}{H}\left(2-\frac{h}{H}\right)}\right] \\
C_{m}=0.773-0.005752 \cdot \theta-0.000026 \cdot \theta^{2}
\end{gathered}
$$

ここで, $M$ : 単位面積当たりの付加質量, $C$ : 圧力係数, $W_{0}$ : 貯水の単位体積重量, $H$ : 貯水池水面加基礎地盤ま での水深, $h$ : 貯水池水面から動水圧が作用寸る点までの 水深, $C_{m}$ : 堤体上流面勾配を考慮した補正係数, $\theta$ : 堤体 上流面勾配である.

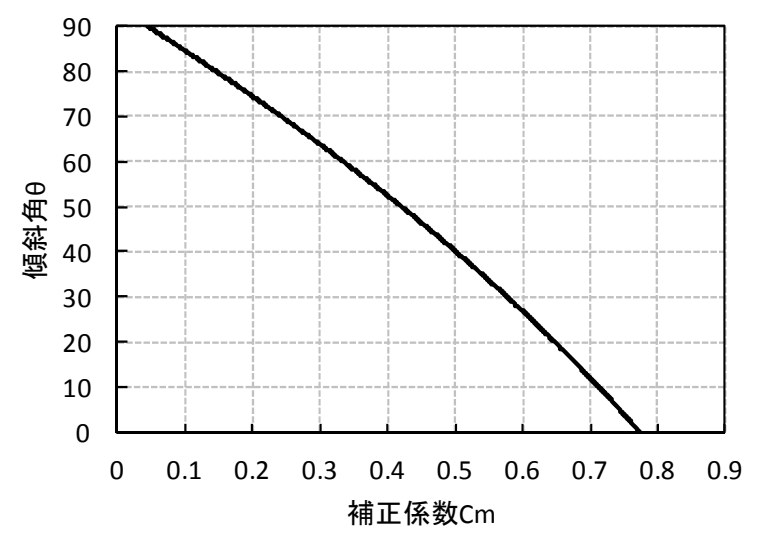

図-5 補正係数 $C_{m}$ と傾斜角 $\theta$ の関係

\section{3. 固有値解析}

アーチダムは常時において, 貯水位に応じて, 鉛直ジョ イント部に剥離・滑動が生じる. 剥離・滑動が生じると, アーチダムを一体構造とした場合と比較して全体岡性が 低下寸るため, 固有振動数に対して影響を与える. 本研究 では, 固有值解析を行う前に常時挙動解析を実施すること でアーチダムの鈆直ジョイント部の剥離・滑動挙動を考慮 した固有值解析を実施した. 実際は, 剥離した要素の岡性 はゼロとなるが，数值解析上の問題から健全時の岡性の 1/1000000の值とした.

\section{（1） 高水位時の固有值解析結果}

貯水条件を高水位（貯水位 $100 \mathrm{~m}$ ）として，各モデルに 対して固有值解析を実施した. 各モデルの低次4次の振動 モード形状を図-6,7,8に, 固有振動数, 各方向 (上下流方 向, 左右岸方向) の刺激係数およひ振動の特徽を表-2, 3, 4 に示す. 図-6より非対称モデルは堤体の非刘称性の影響を 受け, 固有振動モードの形状がやや不規則になっているも のの, 基本的には堤体中央断面を対称軸として, 対称モ一 ドまたは逆対称モードがあらわれていることが分かる. 図 -7,8より右対称モデルおよび左対称モデルでは堤体中央 断面を対称軸として明瞭に対称モードまたは逆対称モー ドがあらわれていることが確認された. 表-2,3,4より，逆 刘称モードにおける上下流方向の刺激係数, および対称モ ードにおける左右岸方向の刺激係数を各モデルで比較す ると, 非対称モデルに比べ右対称モデルおよび左対称モデ ルの場合ではゼロを示している. したがって, 地震時にお いて非対称モデルは振動方向のモードが励起されるだけ ではなく, 振動方向に対して直交する方向のモードも励起 されることが推測される. また，表-2，3，4より非対称モ デルと左対称モデルは上下流モードがより低次に出現し ているのに対して, 右対称モデルは左右岸モードがより低 次に出現しており,解析モデルの差異によって出現する振 動モードに入れ替わりが生じていることが確認できた. 


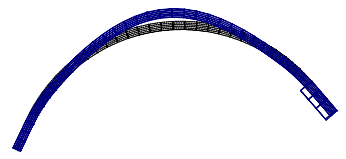

(a) 解析 1 次 $(3.72 \mathrm{~Hz})$

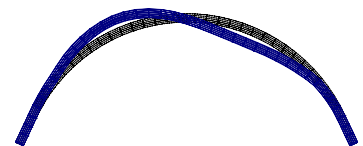

(a) 解析 1 次 $(3.53 \mathrm{~Hz})$

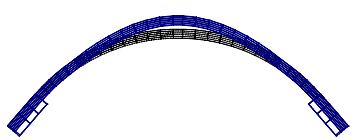

(a) 解析 1 次 $(3.83 \mathrm{~Hz})$

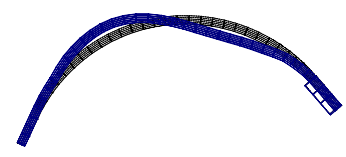

(b) 解析 2 次 $(3.88 \mathrm{~Hz})$

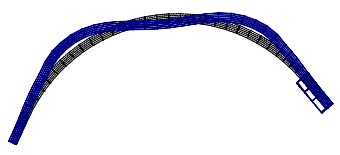

(c) 解析 3 次 $(5.81 \mathrm{~Hz})$

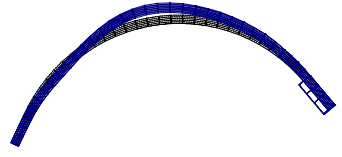

(d) 解析 4 次 $(7.25 \mathrm{~Hz})$

図-6 高水位時の非対称モデルの振動モード

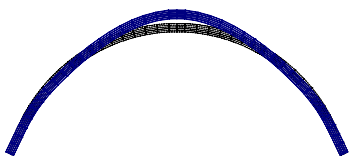

(b) 解析 2 次 $(3.59 \mathrm{~Hz})$

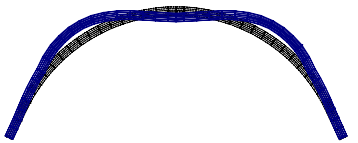

(c) 解析 3 次 $(5.32 \mathrm{~Hz})$

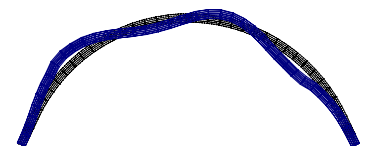

(d) 解析 4 次 $(6.68 \mathrm{~Hz})$

図-7 高水位時の右対称モデルの振動モード

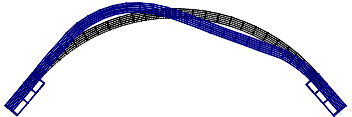

(b) 解析 2 次 $(4.32 \mathrm{~Hz})$

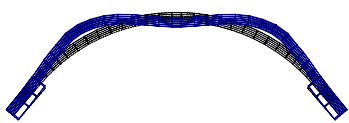

(c) 解析 3 次 $(6.42 \mathrm{~Hz})$

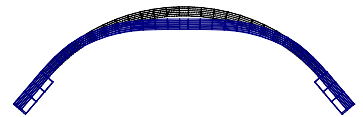

(d) 解析 4 次 $(7.53 \mathrm{~Hz})$

図-8 高水位時の左対称モデルの振動モード

表-2 非対称モデルの固有值解析結果

\begin{tabular}{c|c|c|c|c}
\hline \multirow{2}{*}{ 次数 } & 固有振動数 & \multicolumn{2}{|c|}{ 刺激係数 } & \multirow{2}{*}{ 振動の特徵 } \\
\cline { 3 - 4 } & {$[\mathrm{Hz}]$} & 左右岸方向 & 上下流方向 & 上下流1次(対称) \\
\hline 1 & 3.72 & -0.16 & 2.93 & 上 \\
2 & 3.88 & -1.03 & -0.15 & 左右岸1次(逆対称) \\
3 & 5.81 & -0.07 & 1.89 & 上下流2次 \\
4 & 7.25 & 0.24 & -3.59 & 上下流3次 \\
\hline
\end{tabular}

表-3 右対称モデルの固有值解析結果

\begin{tabular}{c|c|c|c|c}
\hline \multirow{2}{*}{ 次数 } & 固有振動数 & \multicolumn{2}{|c|}{ 刺激係数 } & \multirow{2}{*}{ 振動の特徵 } \\
\cline { 3 - 4 } & {$[\mathrm{Hz}]$} & 左右岸方向 & 上下流方向 & 右右岸1次(逆対称) \\
\hline 1 & 3.53 & -1.01 & 0.00 & 上下流1次(対称) \\
2 & 3.59 & 0.00 & 2.98 & 流 \\
3 & 5.32 & 0.00 & 1.96 & 上下流次 \\
4 & 6.68 & -1.04 & 0.00 & 左右岸2次 \\
\hline
\end{tabular}

表-4 左対称モデルの固有值解析結果

\begin{tabular}{c|c|c|c|c}
\hline \multirow{2}{*}{ 次数 } & 固有振動数 & \multicolumn{2}{|c|}{ 刺激係数 } & \multirow{2}{*}{ 振動の特徵 } \\
\cline { 3 - 4 } & {$[\mathrm{Hz}]$} & 左右岸方向 & 上下流方向 & 上下流1次(対称) \\
\hline 1 & 3.83 & 0.00 & 2.96 & 右右岸1次(逆対称) \\
2 & 4.32 & -0.98 & 0.00 & 上下流2次 \\
3 & 6.42 & 0.00 & 1.98 & 上下流3次 \\
4 & 7.53 & 0.00 & 4.25 & \\
\hline
\end{tabular}

\section{（2）貯水位が固有振動数に及ぼす影響}

貯水条件を空虚時（貯水位 $0 \mathrm{~m} ）$ から $100 \mathrm{~m}$ まで10m刻夕 で11ケースの固有值解析を実施した. また, 鉛直ジョイン 卜部の剥離・滑動挙動が振動特性に及ぼす影響を検討する ため, 剥離・滑動を考慮しない場合の解析結果と剥離・滑 動を考慮した場合の解析結果を比較した. 図-9には各貯水 位に対する各モデルの1次固有振動数を示している. 貯水 位が概ね $280 \mathrm{~m}$ 以上の範囲では, 堤体全体が一体構造として 挙動し, 貯水位の低下に伴う付加質量の減少が支配的とな るため, いずれの解析結果とも, 固有振動数の増加が認め られる。しかし，貯水位が低下寸るに従い，剥離・滑動を

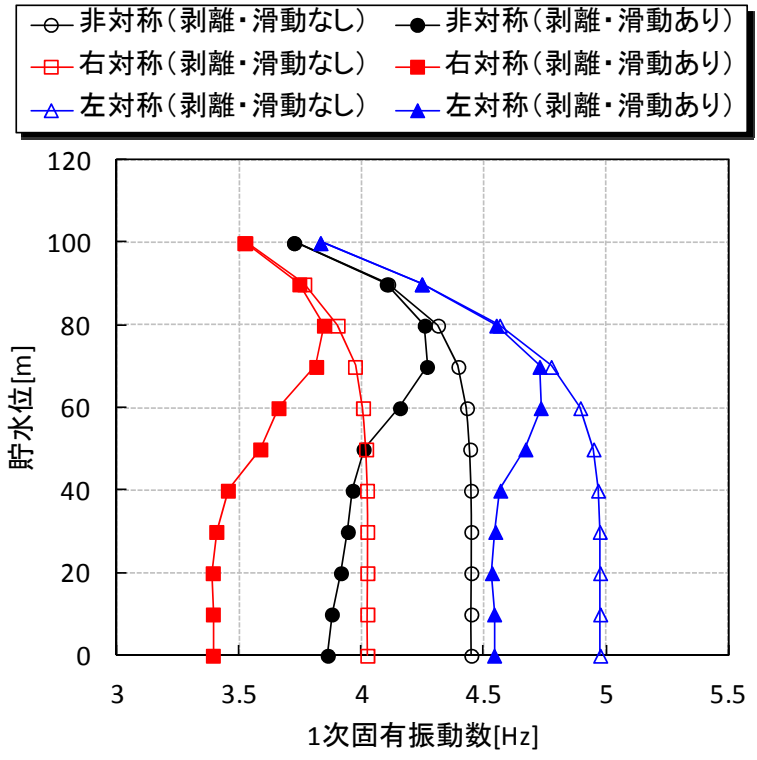

図-9 貯水位と 1 次固有振動数の関係

考慮しない場合の解析では一定值に収束する傾向が確認 できるのに対して,剥離・滑動を考慮した場合の解析では, 貯水位 $80 \mathrm{~m}$ から $40 \mathrm{~m}$ 範囲で鉛直ジョイント部が剥離や 滑動を生じることにより堤体の全体岡性が低下し, 固有振 動数が減少することが推測できる.さらに貯水位が低下寸 ると, 堤体の全体剛性の低下と付加質量の減少が重畳し, 固有振動数はほとんど変化しなくなる傾向が認められる. このような貯水位変動に伴う振動数特性は, 実際のアーチ ダムの常時微動計測を適用した事例》でも報告されてお り,アーチダムの基本的な振動特性における一般的な特徽 と考えられる. また, 非対称モデル, 右対称モデル, 左対 
称モデルの固有振動数に差異が認められるが, これは各モ デルの堤体積の差異に起因していると考えられる. 線形解 析において，貯水位 $0 \mathrm{~m} の$ 場合の非対称モデルの固有振動 数に対する各モデルの固有振動数の比を計算すると, 右対 称モデルは0.90, 左対称モデルは1.12である. 一方，非対 称モデルの堤体積に対する各モデルの堤体積の比を計算 すると, 右対称モデルは1.12, 左対称モデルは0.93である. 一般的に固有振動数は質量の平方根に逆比例するという 関係から, 本解析における各モデルの固有振動数の差異は 堤体積の差異に起因していることが推測できる.

\section{4. 常時挙動解析}

アーチダムの地震時応答には常時における応力状態の 与える影響が大きいことから, 地震応答解析の事前検討と して常時挙動解析を実施した.

\section{（1）荷重条件}

本解析で考慮する作用荷重は, 貯水池の静水圧, 揚圧力, 堤体の自重である.これらは「建設省河川砂防技術基淮(案) 同解説」の従い設定した. 図-10に荷重条件の概略を示す. 揚圧力は上下流方向断面内において鉛直上向きの作用力 として付加し, 堤体上流端で全貯水圧を, 堤体下流端でゼ ロとする三角形分布とした. また, 揚圧力係数は $1 / 3$ とし て算出した. ここでは, 固有值解析の結果を踏まえて, 現 象の境界值として貯水位を $0 \mathrm{~m}$ (空虚)，40m（低水位）， 80m（中間水位），100m（高水位）の4ケースで常時挙動 解析を実施した。

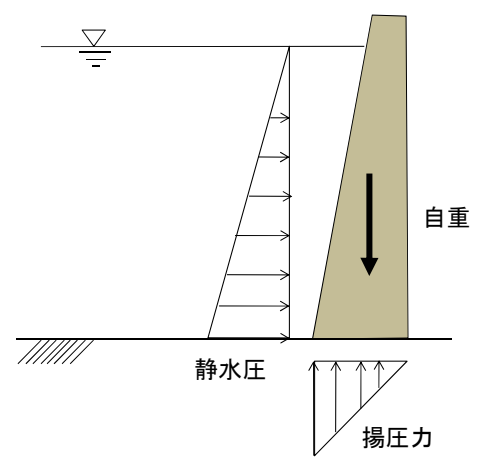

図-10 荷重条件の概略図

\section{(2) 非対称モデルの堤体変形}

非刘称モデルの堤体中央断面の上下流方向変位を図-11 に，堤体天端の上下流方向変位を図-12に示寸. 図-11, 12 より, 空虚から中間水位の貯水条件では, 非線形解析の方 が線形解析よりも堤体の上流側への変形がやや大きい結 果となった. 上流側の変形に伴い, 堤体のアーチ作用が低 減し,鉛直ジョイント部において剥離や滑動が生じたこと が両解析結果に差異をもたらしたと考えられる. 一方, 高
水位時は線形解析結果と非線形解析結果は概ね一致して おり, 静水圧の作用により, 堤体が下流側へ変形し, アー チ推力に寄与寸るアーチ方向圧縮力が増大したことで, 鉛 直ジョイント部に剥離や滑動が生じなかったことが推測 される.また, 空虚から中間水位までは貯水位の上昇に伴 い, 堤体の変位は徐々に増加寸るが, 中間水位から高水位 では変位が急増し，2次曲線的な変動を示している．これ は堤体がV字型であるため貯水位の増加に伴い静水圧が 作用する堤体上流面の面積が急増するのに加え，堤体高位 が高くなるに従い, 堤体断面厚さが薄くなることが起因し ており, 高水位では水位の増加に対してより敏感に挙動す ることが推測される.

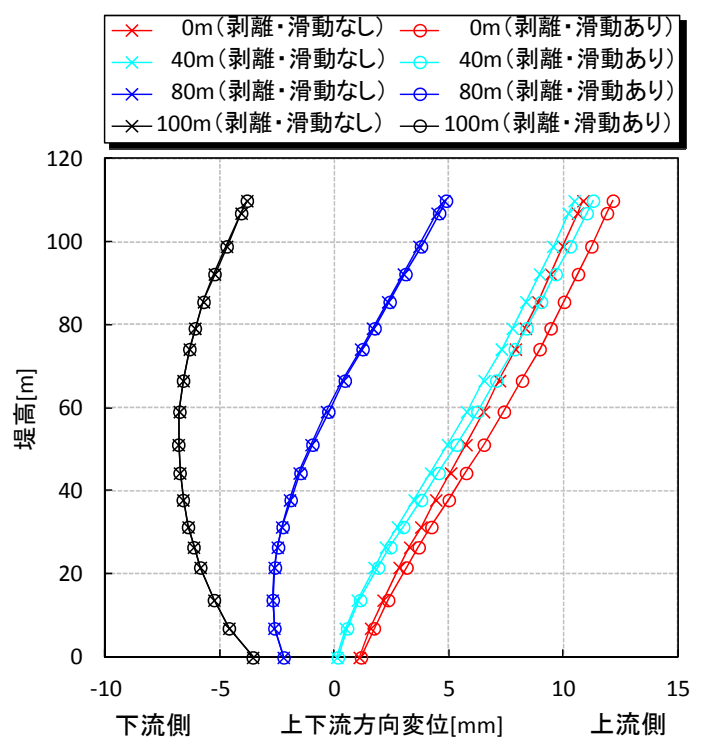

図-11 非対称モデルにおける堤体中央断面の変位

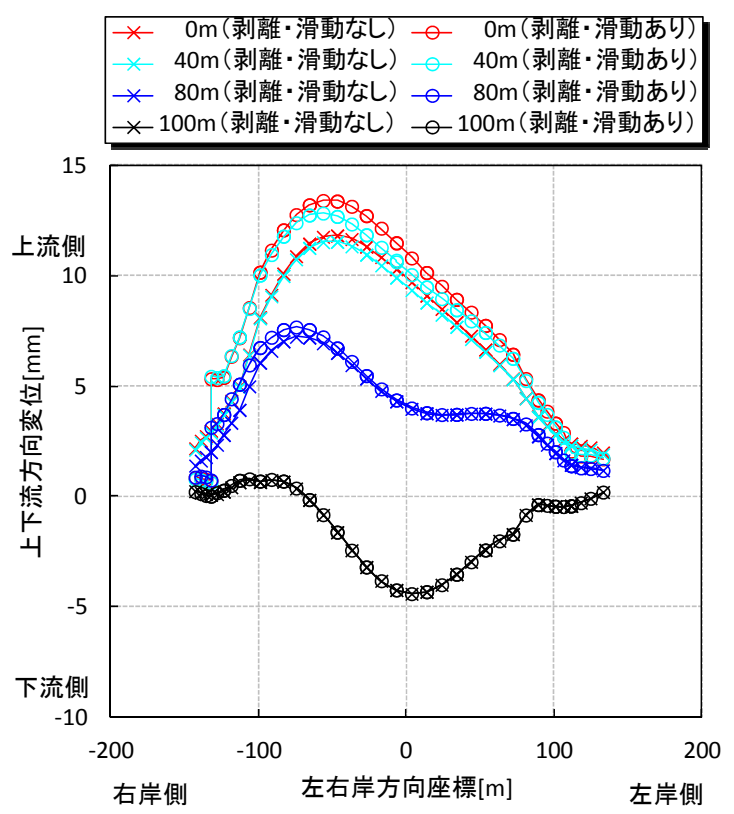

図-12 非対称モデルにおける堤体天端の変位 


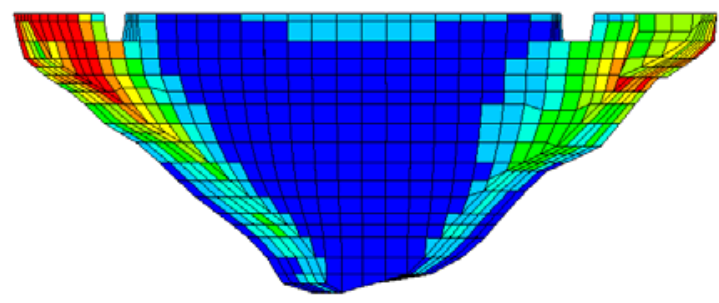

(a) 空虚時 (線形解析)

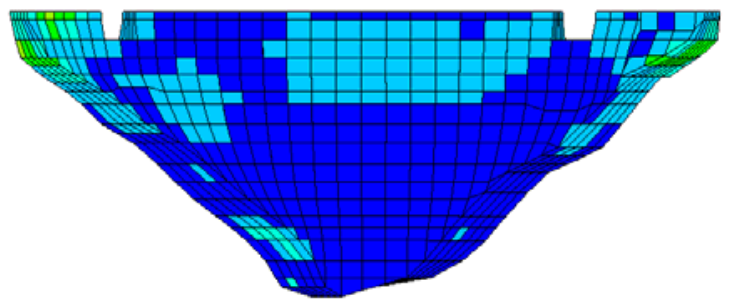

(c) 高水位時 (線形解析)

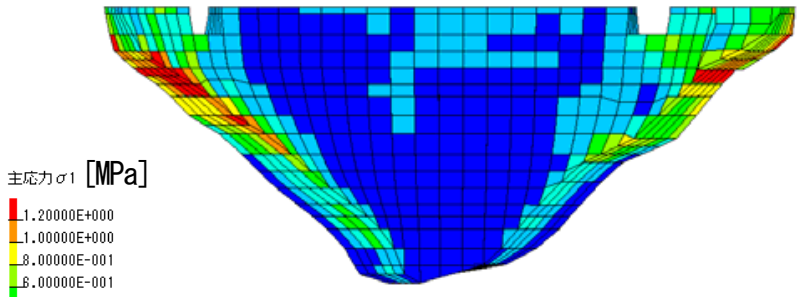

(b) 空虚時 (非線形解析)

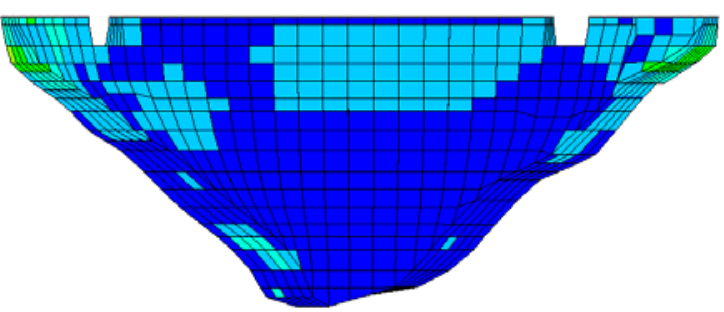

(d) 高水位時 (非線形解析)

図-13 非対称モデルの最大主応力分布図

\section{(3) 非対称モデルの堤体応力}

空虚時と高水位時の非対称モデルの最大主応力分布を 線形解析と非線形解析で比較検討する. 空虚時および高水 位時における最大主応力分布図を図-13に示す. 既往の研 究8)によるとダムコンクリートの圧縮強度は約 $30 \mathrm{MPa}, 引$ 張強度は3〜 5MPaとされており, 今回の常時挙動解析条件 下においては圧縮応力および引張応力ともに許容值より 小さい結果となった。 図-13より, 空虚時は線形解析と非 線形解析で応力分布に差異が認められる. 前述したように, 空虚時は堤体が上流側一変形することにより,ア一チ方向 圧縮力が低減し, 鉛直ジョイント部において剥離や滑動が 生じることが推測できる. 線形解析では, 鉛直ジョイント 部の非線形挙動を考慮していないため, 堤体が一体となっ て変形し, 図-13(a)のように右岸側堤体天端にやや大きな 引張応力が生じている. 図-13(b)より非線形解析では, 線 形解析で強い引張㐫力が発生した部分において鉛直ジョ イント部が剥離または滑動し, 水平ア一千方向の引張応力 が解放され, 鉛直片持ち梁的な曲げ変形に伴う引張応力が 岩着部付近で生じたと考えられる. 高水位時は, 両解析結 果が概ね一致しており, 貯水位の増加に伴う静水圧の影響 によりアーチ推力に寄与するアーチ方向圧縮力が発生し, 鉛直ジョイント部において剥離や滑動が生じなかったこ とが推測できる. 前述した貯水位変動に伴うダム堤体の変 形特性と併せると, 貯水の存在がアーチダムの安定性に対 し有利に作用していることが確認された. 既往の研究9 に よって本解析で用いている解析モデルのように堤体下流 面にオーバーハングがない, あるいは小さいアーチダムで は空虚時にダム堤体の安定性に重大な影響を及ぼす可能 性があることが指摘されており, 現行の而震設計法では堤 体下流面にオーバーハングを設けることが義務付けられ ている.

\section{（4）対称モデルと非対称モデルの比較}

ここではダム堤体の左右対称性および非対称性が常時 挙動に及ぼす影響について検討する.解析結果の一例とし て, 空虚時に各モデルに対して線形常時挙動解析を実施し た場合の最大主応力分布図を図-14に示す. 図-14より, 非 対称モデルの右岸側の応力分布図は右対称モデルの応力 分布と概ね一致しており, 非対称モデルの左岸側の応力分 布図も左対称モデルの応力分布と概ね一致していること が確認できる. この解析ケースに限らず, 他の解析ケース においても同様の結果が得られている. したがって, 堤体 の非対称的な形状特性が常時挙動に対して及ぼす影響は 小さいことが確認された.

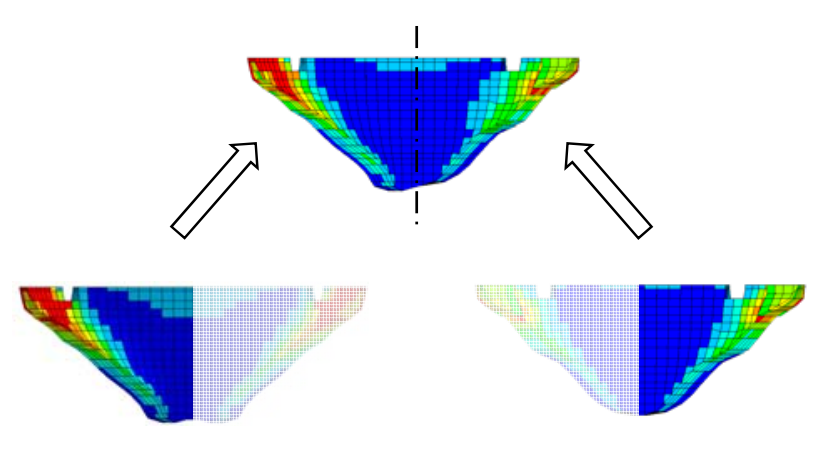

図-14 対称モデルと非対称モデルの比較

\section{5. 結論}

本検討では, 鉛直ジョイント部の剥離・滑動挙動を考慮 した固有值解析および常時挙動解析を実施した. さらに, アーチダムの形状に着目し, 実在するアーチダムから作成 した三次元有限要素解析モデルを非対称モデルと位置づ 
けた. 非刘称モデルをもとに左右刘称的な堤体を有寸る解 析モデルを2ケース構築し, 計3ケースの解析モデルに対し て, 固有值解析および常時挙動解析を実施した. その結果, それぞれの解析モデルの振動特性および常時挙動につい て検討した. 以下に得られた主な結論を示す。

（1）地震時において, 非対称モデルは振動方向のモードが 励起されるだけではなく, 振動方向に直交する方向の モードも励起されることが推測される.

(2) 貯水位に応じた鉛直ジョイント部の剥離・滑動挙動を 考慮した固有值解析を実施することで，アーチダムの 固有振動数と貯水位の関係を把握した. 高水位では, 貯水位が低下寸るに従い付加質量効果が支配的とな り, 固有振動数は増加寸る. しかし, ある貯水位以下 になると，付加質量効果よりも鉛直ジョイント部の剥 離・滑動に伴う堤体の全体剛性低下の影響が優位とな り, 固有振動数は低減する. さらに貯水位が低下寸る と概ね一定の固有振動数に収束する.

(3) 常時挙動解析により, 空虚時には堤体が全体的に上流 側へ変形し,アーチ作用が低減することで鉛直ジョイ ント部において剥離や滑動が認められた。一方, 高水 位時は貯水池の静水圧増加に伴い, 下流側一堤体が変 形し，アーチ推力に寄与するアーチ方向圧縮力を増大 させ，鉛直ジョイント部で剥離・滑動が生じることな く一体構造として応答した. このことから, 貯水の存 在はアーチダムの安定性に有利に作用したことが確 認された.

（4）常時挙動解析によって対称モデルおよび非対称モデ ルの最大主応力分布の比較を行った. 解析結果より, 非対称モデルの左右の応力分布は対称モデルの応力 分布と概水一致寸ることが確認され，常時挙動に関し て堤体の左右対称性が及ぼす影響は小さいことが示 唆された.

\section{参考文献}

1）豊田幸宏，上田稔 : 現場計測データに基づくアーチダム一岩 盤一貯水系の3次元時刻歴応答解析法の適用性検討, 電力中 央研究所報告(U00025), 2000.

2）日本大ダム会議 : ダム設計基淮（第2次改訂），1978.

3）西内達雄, 松井淳, 大熊信之: 三次元非線形有限要素解析を 用いたアーチダム耐荷機構の解明, 電力中央研究所報告 (N09018), 2010.

4) 西内達雄, 阪田憲次 : 鉛直方向の施工ジョイント部での離接 を考慮したアーチダムの常時挙動解析, 土木学会論文集E Vol.62, No.4, pp.672-688, 2006.

5) 株式会社アーク情報システム:TDAPIII理論説明書 バージョ ン3.01, 2008.

6）建設省，建設省河川砂防技術基淮（案）同解説，1985.

7) Okuma, N., Etou, Y., Kanazawa, K. and Hirata, K. : Dynamic properties of a large arch dam after forty-four years of completion, World Conference on Earthquake Engineering, Paper No. 0173, 2008.

8) 畑野正 : コンクリートの如き脆性体のひずみに立脚した破壊 論, 土木学会論文集(No.153), pp.31-39, 1968.

9) 渡辺哲行, ラザビソヘイ，高島賢二，谷山尚：ペリメータ 沿いのジョイントと鉛直ジョイントの開ロがコンクリートア 一チダムの地震応答に与える影響, ダム工学, Vol.9, No.2, pp.79-94, 1999.

(2011. 12.9受付、2012. 2. 29修正、2012.3.6受理)

\title{
EVALUATION ON ARCH DAMS CONSIDERING NONLINEAR BEHAVIOR OF TRANSVERSE JOINTS ON VIBRATION CHARACTERISTICS AND STATIC BEHAVIOR
}

\author{
Taiji MAZDA, Nobuyuki OKUMA, Yohei ENDO and Elif Cargda KANDEMIR
}

Thin structures of the arch dams are influenced by the interaction of foundational rock and reservoir. In this research, transverse joints have been confirmed to open and slip. In each dam site, a dam body shape has wide variety shape, however that dam body shape effect on static behavior has not been clarified. In this paper, an analytical model considering the nonlinear characteristics of the transverse joints is built, and a symmetric and asymmetric model is modeled as the three dimensional models which have a dam body - foundational rock - reservoir system. In order to find out a vibration characteristics and resistance mechanism, each model is analyzed by the eigenvalue analysis and static behavior analysis. 